\title{
FASHIONING CONSUMERS: ACKeRMANN'S REPOSITORY OF ARTS AND the CuLTIVATION OF THE Female CONSUMER
}

\author{
Serena Dyer
}

\begin{abstract}
C ONSUMPTION HAS SERVED as one of the key explanatory frameworks for economic and social change in eighteenth-century Britain. The influence of consumption on debates surrounding political and moral economy has been undeniable, inspiring the application of transformative phrases - such as the 'consumer revolution' and 'consumer society' - to characterise the century (McKendrick et al. 1982; Langford 1989). Yet, amidst the rich and interdisciplinary literature on the growth of a 'consumer society', little attention has been paid to the figure at the heart of this debate: the consumer. Key questions remain regarding who these consumers were, how they were perceived, and how they were cultivated. In particular, the female consumer, who was the subject of extensive contemporary comment, has been obscured by a veil of disapproving, and at times misogynistic suspicion (Styles and Vickery 2006: 2). This gendered stereotype of the consumer has simultaneously been painted by contemporary commentators as an idle browser, an extravagant spendthrift, and a careful housekeeper (Smith 2012). Yet, toward the end of the long eighteenth century, this contradictory consumer character gained clarity and definition in the public eye. These decades bore witness to the emergence of a new, productive consumer character, who epitomised patriotic spending and polite fashionability.

The periodical press played a fundamental role in the formulation and dissemination of the figure of the productive female consumer: both in terms of her public representation, and her practical guidance. Epitomised by Rudolph Ackermann's Repository of Arts (1809-28), upon which this chapter will focus, such periodicals first propagated an ideal consumer character and practice, and then guided their readership toward embodying that character. Aside from encouraging their intrinsic consumption of the periodicals themselves, editors also guided the readership in their consumption of fashionable dress and furniture, as well as ceramics, glass, books, and the various components of the domestic interior. In other words, the periodical press encouraged its readers to appreciate, and potentially purchase, a specific, polite, and metropolitan set of material goods.

For middling and elite women, being part of fashionable urban society was not only expressed by who you were and how much money you had, but also, and perhaps more importantly, through your engagement with the new world of goods (Batchelor
\end{abstract}


and Kaplan 2007: 1; Greig 2013). These new luxury goods could display taste and promote industry; however, they were by no means easy to navigate (Berg and Eger 2002: 61). Indeed, the pitfalls of misjudging your consumption could lead to ridicule and social exclusion (Vickery 1998: 219). A myriad of considerations, including taste, quality, workmanship, patriotism, patronage, and suitability meant that the consumer needed more information about the goods available to them than simply to know what was fashionable. By the early nineteenth century, the periodical press recognised and responded to this need, expanding upon the now-established fashion plate to arm its female consumer-readers with the information required to access the material culture of metropolitan polite society. In this chapter, I argue that the periodical provided a key tool for the female consumer, helping to hone her consumer skills, and guide her spending.

\section{The Productive and Patriotic Consumer}

The figure of the productive, patriotic consumer provides the key link between the material world of goods and the economic market. British economist Daniel Boileau wrote in 1811 that consumers could be 'divided into productive and unproductive', with the latter characterised by their idleness, and the former by their contribution to 'the community at large' (1811: 365). The idle, frivolous consumer was a long-standing trope and, constructed through the male gaze, has been responsible for masking careful and skilled browsing as an irresponsible and irreverent leisure activity (Kowaleski-Wallace 1997: 73-108; McCreery 2004: 139). As early as 1712, the Spectator, in no. 336 (26 March) contained a fictionalised letter in which Rebecca, a china retailer, described these women as 'Female Rakes' (Addison 1965, vol. 3: 245). The rake, traditionally a male figure, was characterised both by his social status, and his criminality. However, the rake's negative, violent, and criminal features were often overlooked because of his assumed prestigious and elite status (Mackie 2009: 35). The characterisation of idle consumers as female rakes accorded them a similar status: public menaces and a nuisance to commerce, yet entertained by retailers, and shielded from general censure, due to their elite status. As they 'tumble Silks they have no mind to buy', these consumers were depicted as enacting consumption as a fashionable pastime, but failing to engage with their economic responsibility to purchase (Campbell 1747: 197). In other words, they were seen to browse for their personal pleasure and the social spectacle, but to neglect to consume for the public commercial good.

However, the work of Helen Berry and Kate Smith has revealed that the browsing practice at the heart of women's vilified consumption habits not only enabled women to express their financial awareness through bargaining, but also required the use of haptic skills to assess the quality and workmanship of items (Berry 2002a; Smith 2012). By looking at, handling, and discussing goods with retailers, consumers were able to build up both a somatic memory of the objects on offer, and a more general knowledge of the market, enabling them to make sound consumer decisions. These twinned skills of economic and material literacy were central to the productive consumer figure of the late eighteenth and early nineteenth century. Perhaps most importantly, acknowledging these skills recognises that the consumer engaged with the commercial market in a productive way not only through purchasing, but also through the purposeful browsing of goods in order to gain material and market knowledge. Productive consumption 
could not take place without premeditated browsing - a key concept which the periodical would come to acknowledge.

Material and economic literacy were key traits of the productive consumer; however, these skills alone were not enough to benefit 'the community at large' (Boileau 1811: 365). To be a truly productive consumer required a greater awareness of the implications - both economic and social - of your consumption. Frank Trentmann has argued that consumption practices did not lead to the development of any sort of consumer consciousness in the eighteenth century, yet the notion of social conscience as a motivation for consumption, or non-consumption, is frequently evident in this period (Trentmann 2006: 19-70). Perhaps the most apparent example of this conscientious consumption was the abolitionist boycott of sugar, itself discussed in the Repository of Arts (Ackermann 1809: 1, 167-70; McDonald and Topik 2008: 109-27). Similarly, the 'buy Irish' campaign following the Act of Union in 1801 promoted the consumption of Irish linen in order to support the intertwined British economy (Powell 2013: 282-302).

Patriotic consumption was increasingly popular among the polite urban elite toward the end of the century. Queen Charlotte, wife of George III, and her daughters were recorded as having a 'patriotic sense of duty toward the struggling Spitalfields silk industry' in 1791 (Lister 2003: 56). In the same year, the Society for the Improvement of British Wool was established by Sir John Sinclair, which linked the promotion of British products with the improvement of product quality and agricultural methods (Gascoigne 1994: 189). By the 1830s, the concept of 'buying British' was established as a patriotic and conscious consumer action. Indeed, it was even discussed in a House of Commons debate in 1838 that all attendants at the coronation of Queen Victoria should be seen to wear British manufactured garments (HC Deb 30 Apr 1838, 42, cc674-5). This notion - to be seen to purchase in order to promote trade and industry - was advocated in the printed press, both through explicit advertising, and through the more implicit espousal of polite, metropolitan British values (Berry 2002b: 1-17). The shift toward the recognition of a conscious consumer can be read as only part of a broader change in British economic structure, from one based on trade to one based on industry (Berg 1994). The productive consumer articulated in periodical publications was a key component of a national character built around commerce and manufactures.

\section{Shops and the Consumer in Ackermann's Repository of Arts}

As a periodical, Ackermann's Repository of Arts, Literature, Commerce, Manufactures, Fashions, and Politics epitomises the values of the productive, patriotic consumer. The publication as a whole began with no clear gendered audience - setting it apart from previous periodicals that had guided female consumers through fashion plates and news. Its articles were varied and wide ranging, conforming to Ackermann's claim that he wanted the Repository of Arts to 'beguile the unlearned into an acquaintance with the arts and sciences - and occasionally to assist even the man of letters in cultivating a taste for both' (1 (Jan 1809): 3). The periodical presented a world of modern learning, merging poetry and fashionable goods with political news and scientific essays. The readers of the Repository of Arts - both male and female - were encouraged to engage 
with this modern, urban world not only as passive readers, but also as consumers. The Repository of Arts foregrounded the consumer as a core component of the magazine's readership, and identified and played off the marriage between the consumer and the British patriot, and between the consumer and polite urban culture. Not only did the publication provide a series describing various metropolitan shops, it also contained innovative fabric sample pages, as well as fashion plates and images of fashionable furniture. This multifaceted approach to guiding the consumer character reveals a nuanced relationship between the periodical and the commercial market.

Rudolph Ackermann (1764-1834), the publisher and editor of the Repository of Arts, was an Anglo-German bookseller, inventor, and businessman. Originally a carriage designer, he prized invention and innovation. He patented a method for waterproofing cloth, and maintained a strong interest in science, which was reflected in the essays in the Repository of Arts. One of Ackermann's first publications, drawn from his early work as a carriage designer, was Imitations of Drawings of Fashionable Carriages, published in 1791, which he quickly followed with further books of designs. By 1794, he published under his own imprint, and within the decade, he had established 101 The Strand as a publishers and drawing school, which he named the Repository of Arts in 1798. Nearly a decade later, Ackermann included an image of the interior of 101 The Strand in the first volume of the Repository of Arts in its periodical form, explicitly linking the publication with the establishment from which it originated (Fig. 30.1). This image, and its accompanying description, marked the 'commencement of a series of plates intended to exhibit the principal shops of this great metropolis' (1 (Jan 1809): 53). This commercial appropriation of the same format Ackermann used in his Microcosm of London series (1808-10) demonstrates the explicit focus of the Repository of Arts on polite urban culture. Microcosm of London was a three-volume set containing 104 aquatints depicting the interior and exterior of London's major buildings and their inhabitants, reflecting Ackermann's focus 'on the social and cultural institutions of London, the theatres, the shops, and the markets; the things that made the city an exciting and interesting place' (Bermingham 2000: 135).

The marriage between the commercial and the urban is apparent throughout the periodical, and was by no means a new concept. The pre-eminence of London fashion had long been acknowledged. In 1773 the Lady's Magazine provided an often-quoted narrative on the usual progress of fashion information:

If a lady of elevated rank ... should ... dress herself in a particular manner, all the rest of the sex would adopt her ton of dress ... the contagion commences from those who are familiar with the person who introduces the new mode; after which it communicates itself to their acquaintances or those who behold them ... from the city it spreads to the country. (1773: 199-200)

This explanation for the emerging fashion plate - published over thirty years prior to the first edition of the Repository of Arts - exemplifies not only a provincial desire for elite urban fashions, but also a thirst for visual access to them. Fashion news itself - as it may have been obtained through letters or the descriptions given by proxy shoppers - was not sufficient (Vickery 1993: 280; Lambert 2009). For consumers of fashionable 


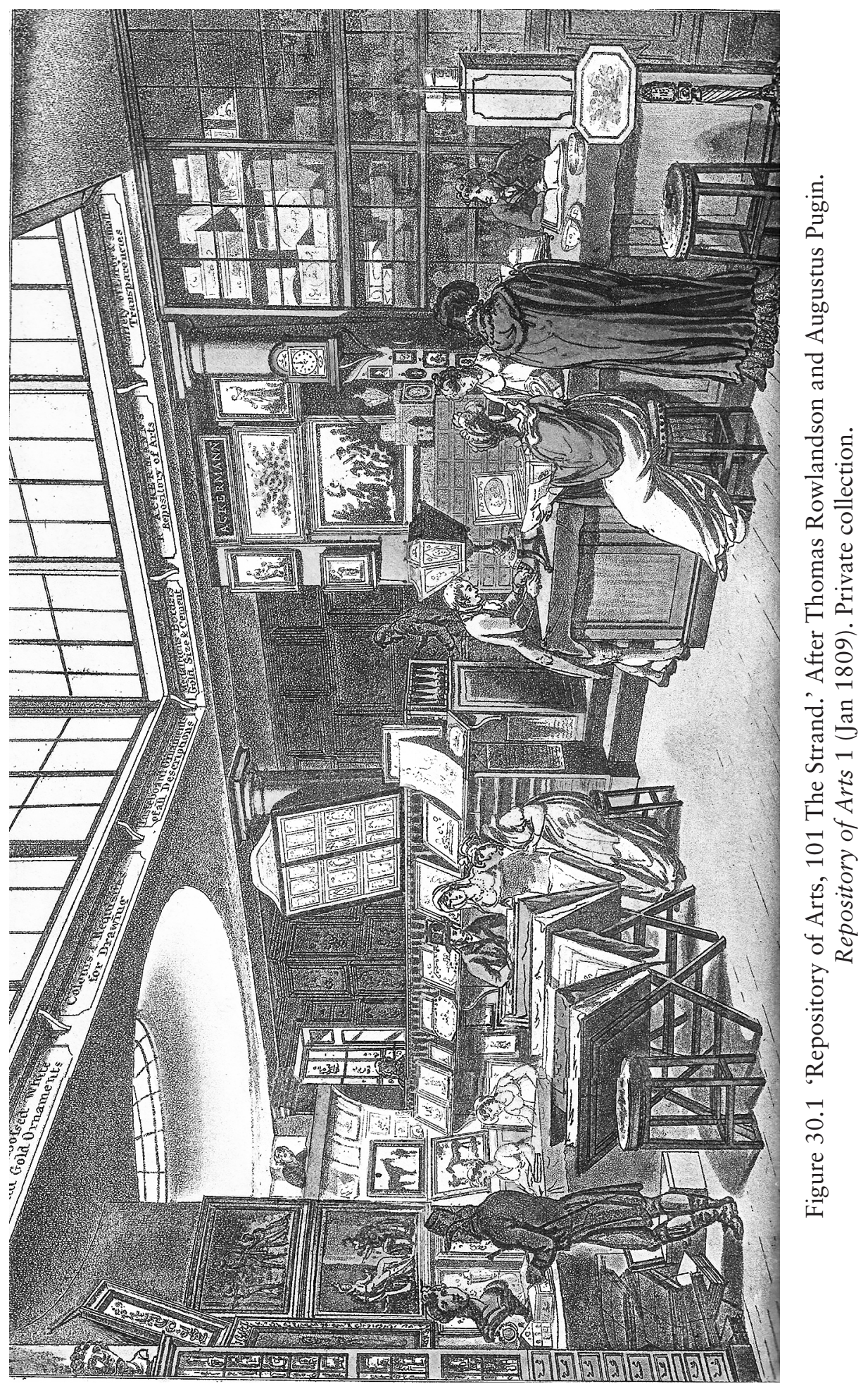


goods, visual access to the material urban world was essential, alongside explanations of what they were looking at.

The lively vigour and vitality of the images included in both Microcosm of London and the Repository of Arts is characteristic of Ackermann's use of visual sources to drive the content of his publications. Indeed, the accompanying text of Microcosm of London - primarily descriptions of the images - was verbose at best. The images themselves were created through a partnership between Augustus Pugin (1762-1832), an Anglo-French architectural draughtsman and father of the Gothic architect, and Thomas Rowlandson (1756-1827), the caricaturist (Ford 1983: 39). The images they produced were an ingenious merging of the pair's skills, in which Pugin's detailed and architecturally exact settings were inhabited by Rowlandson's characterful and vivid figures.

Rowlandson and Pugin were again employed to produce the image of the interior of 101 The Strand for the Repository of Arts in 1809, as well as a number of the subsequent images in the series. The unique visual style of this partnership meant that these images not only depicted what the shops looked like, but also how people shopped there. On the one hand this was a voyeuristic view into a fashionable urban lifestyle. However, it also afforded readers with a mimetic experience, which they could replicate through their own shopping practice. The figures depicted are not passive - instead they actively engage with their surroundings. They leaf through portfolios, talk with the shop assistants, and inspect the artworks, curiosities, and sculptures that adorn the room. Through these images, the readership of the Repository of Arts was invited to see themselves as the inhabitants of the space depicted, whilst simultaneously being subtly instructed how to interact with the goods within the shop. In a later image in the series Messrs Harding and Howell, a haberdasher's and draper's shop, is depicted. In this image female consumers touch and handle fabric, inspecting its drape and movement (1 (Mar 1809): 187). Similarly, in an image of Wedgwood's Rooms, female consumers hold and handle pottery, feeling its weight and balance (1 (Jan 1809): 102). Through engaging in the browsing practice depicted in the Repository of Arts, consumers could uncover faults and flaws, gauge suitability, and develop their personal material literacy (Smith 2014: 150). In other words, the shop series in the Repository of Arts was an endorsement of the productive browsing process identified by Smith and Berry (Berry 2002a; Smith 2012: 3-4). It simultaneously promoted and disseminated this productive consumer behaviour.

The Repository of Arts' shop series was diluted with other, non-commercial establishments by the end of 1809, such as the Bank of England and the houses of various prestigious families. However, the initial goal stated by Ackermann had been to focus on shops, his explicit intention being to 'afford the opportunity of entering into a partial detail of the different manufactures that are exposed in them for sale' (1 (Jan 1809): 53). In the text accompanying the image of his own establishment, Ackermann not only took advantage of the opportunity to advertise the subscription prices for his circulating library of prints, but also provided a detailed history of the previous uses of the building. In doing so, the Repository of Arts - both as a shop and a periodical - meshed the cultural and social prestige of its aristocratic background as the home of the Beaufort family, with the commercial and economic productivity of its current use. The Repository of Arts was simultaneously a means of entrepreneurial selfpromotion, and of advocating the polite urban lifestyle with which it associated itself. 
The second subject of the shop series, Wedgwood's Rooms, was the most complete and thorough account of any of the shops, providing a full history of pottery, the production process, and the interior of the shop. Furthermore, it explicitly engaged with the vocabulary of the patriotic consumer, foregrounding Josiah Wedgwood's position as an iconic British manufacturer. Ackermann openly acknowledged Wedgwood's importance in the accompanying text, stating that 'the potteries are so truly British manufactures, are of so much importance to commerce, and add a lustre even to the arts of the country' (1 (Jan 1809): 102). Through marrying Britishness with commerce and the arts, Ackermann again emphasised his interlinked ideals of commercial patriotism, invention and innovation, and polite urban taste. Wedgwood's pottery was not only the product of 'fertile genius' and 'extraordinary discoveries', but was also explicitly British.

Production also emerges as a key focus of the Repository of Arts series on shops. The artificial division often placed between production and consumption in scholarly work has been questioned by Maureen Daly Goggin, Beth Fowkes Tobin, and Kate Smith (Goggin and Tobin 2009; Smith 2014: 85-7). Not only, as Smith has argued, are the consumers depicted in the accompanying image of the Wedgwood Rooms shown haptically to inspect the quality and workmanship of the objects they are browsing; but also, through the Repository of Arts, they were provided with a detailed description of how the objects were made. This description was by no means superficial, perhaps reflecting Ackermann's personal interest in manufactures and invention. It not only described the process of producing basic pottery - from the initial treatment of the clay through to the final firing - but also described four different types of pottery manufactured by Wedgwood: terracotta, Basaltes, porcelain bisque, and the iconic Jasperware. This knowledge of production was key to the material literacy of consumers, and was simultaneously a means of polite education, and of developing practical judgement.

Sadly, the detail provided in relation to Wedgwood's manufacturing processes was not repeated in the subsequent articles in the shop series. Pieces on other metropolitan shops followed, such as Messrs Harding and Howell, haberdashers and drapers, Messrs Lackington, Allen and Co., booksellers, and Messrs Pellatt and Green, glassmakers. However, these entries follow a more descriptive pattern, recounting the varieties of goods on offer, and occasionally providing a brief history of the trade or manufacture to which the shop belonged (1 (1809): 187, 251, 330). We learn, for example, that upon first entering Messrs Harding and Howell, the visitor would first be confronted with an area 'exclusively appropriated to the sale of furs and fans', followed by a second department containing 'articles of haberdashery of every description, silks, muslins, lace, gloves \&c.' (1 (1809): 187). These descriptions often read more like contemporary advertisements and trade cards, listing what might be purchased, with only the brief histories of the establishments setting them apart (Berg and Clifford 2007). Ackermann's interest in invention and innovation re-emerges in relation to the invention of Messrs Pellatt and Green's patent for a glass invention that allowed light into the interiors of ships and buildings; however, this information bears little relevance to the consumer who might visit the shop to view decorative glassware, as is depicted in the accompanying image. This inconsistency should not, however, be read as a faltering resolve in relation to the publication's intent to guide and cultivate the British consumer character. Indeed, it instead provided an opportunity to revaluate and refocus how the publication integrated its various strands of consumer guidance. 


\section{Fashion and Furniture}

When a shop was again revisited in the series, it was fashionable furniture store Messrs Morgan and Sanders's Ware-Room, on Catherine Street off the Strand - a nearby neighbour of Ackermann's (2 (1809): 122; Beard and Goodison 1987: 241). Unlike previous entries, this shop, which primarily sold furniture and soft furnishings, was closely linked to other aspects of, and articles published in, the Repository of Arts. The article began by referencing a piece in a previous edition on historical customs, and draws a direct comparison between the 'simple habitations' of our 'good forefathers', described in the earlier essay, with the 'innumerable conveniences and luxuries' which were available in this shop. The Repository of Arts enthusiastically wrote that 'perfection, modern ingenuity and invention have arrived' in the articles of furniture on display in this shop. Again, Ackermann's rhetoric of modernity, invention, and patriotism is evident. This furniture, the piece enthusiastically states, is an example of the 'beauty of design, and exquisite workmanship ... manufactured in the metropolis of the British empire' (2 (Aug 1809): 123). However, it is tempered with a greater awareness of what the consumer-reader might want to know. Production and manufactures are touched on, as is prestigious royal patronage, and the 'honour and integrity' of the retailers. In other words, the piece articulates that this shop provided the highest quality manufactured goods, with elite patronage, and from trustworthy retailers.

Prints of 'Fashionable Furniture' were a key fixture of the publication from the outset; although they were not as long-standing as the fashion plate, which continued to be a component of every volume in the Repository of Arts' nineteen-year run. The prints followed in the footsteps of the furniture catalogues of the second half of the eighteenth century. A tradition begun by Thomas Chippendale's 1754 catalogue, Thomas Sheraton, George Hepplewhite, and numerous other cabinetmakers had followed suit (Vickery 2009: 279). These furniture manuals provided an attractive means for genteel consumers to educate themselves about current fashionable designs and styles. Novelty and choice - identified as two of the key driving factors behind eighteenth-century consumer culture - were offered in these pages (Bianchi 1998). Just as the magazine as a whole encapsulated the values of polite urban society, Ackermann's replication of the furniture catalogue format in the pages of the Repository of Arts provided readers with access to these compendiums of fashionable furniture in miniature. However, they also provided an additional sense of the rapidity of changing fashions. While the makers' catalogues were not frequently updated, the Repository of Arts was able to boast an almost monthly update on what they interpreted as fashionable and desirable at that moment. This simultaneously manufactured and cemented the periodical's own vital importance as a key tool to navigate these rapidly changing fashions, as is also reflected in Chloe Wigston Smith's contribution to this volume.

Indeed, the Repository of Arts did not blithely and passively recount fashions instead it confidently trained and guided its readership. That the magazine was designed to articulate Ackermann's polite, urban agenda is apparent in the willingness to convey strong opinions in regard to fashionable goods. For example, in August 1809, the description that accompanied the plate showing fashionable furniture confidently berated the 'barbarous Egyptian' style, which had recently prevailed in fashionable circles (2 (1809): 132). Instead, the volume declared that 'the classic elegance which 
characterised the most polished ages of Greece and Rome' should be preferred. Key traits of 'taste', 'skill', and 'ingenuity' are again foregrounded in the text describing the image of the classically styled ladies' toilette furniture, which accompanied this declaration of aesthetic preference.

Aside from the fashion plates and ladies' fashion news, the Fashionable Furniture prints provide one of the few areas of the periodical that was explicitly gendered from an early stage. Amanda Vickery has argued that the eighteenth century bore witness to a blossoming language of 'his and hers' in relation to furniture (Vickery 2006). These pieces displayed little difference in terms of construction, aesthetic, materials, or decorative motifs. It was not the case that the soft rococo styles were favoured by women, and the strong lines of the neoclassical reserved for men (Vickery 2009: 280). Instead, women's furniture was smaller and neater, while men's was more robust and functional (Beard and Goodison 1987: 205). The Repository of Arts conformed to this gendered language of furniture, and most commonly presented ladies' furniture.

In 1814 the Fashionable Furniture section described a 'lady's book-case' (11 (Oct 1814): 178). It is described (see Plate 5) as being 'calculated for a lady's boudoir, being extremely light, and occupying a very small space'. That it is 'pleasing', 'elegant', and 'tasteful' are key selling points in the text. The accompanying image depicts a neat and elegant piece of furniture. It illustrates how it might be used, with books nestled in the shelves at the back, the silk curtains slightly pulled back from the fretwork doors, and a drawer - perhaps for storing letters - pulled out below. Not only did the Repository of Arts display to its readers the aesthetic styles which were fashionable, it showed them how they worked and how to use them. Although early editions did include scales or measures, the focus on aesthetics and use was quite a contrast to that of the catalogues and directories of cabinetmakers, which generally provided more technical drawings, showing plan views and dimensions rather than focusing on domestic utility (Vickery 2009: 280-1; Shimbo 2016: 31-4). However, much like the furniture-makers' catalogues, advertisement was a central part of the purpose of this feature. The cabinet depicted was manufactured by Messrs Morgan and Sanders - the very establishment which had appeared in the shops series five years previously, attesting to an ongoing commercial network between Ackermann and other retailers. The inclusion of such images was specifically aimed at consumers, utilising the magazine format to directly appeal to potential customers. Readers were simultaneously informed that this particular design was fashionable and desirable, shown how it might be used within their own home, and given all the information required to purchase it. Indeed, a similar device was employed for the ladies' fashions. For example, in the same volume as the lady's bookcase, the cloaks and gowns depicted in the fashion plates are attributed to Mrs Gill of Cork Street, whom the Repository of Arts credits with 'taste and invention' (11 (Apr 1814): 241).

Aside from promoting the wares of specific retailers, the Fashionable Furniture section of the Repository of Arts was also used to perpetuate the periodical's focus on patriotic British manufactures, and on the cultivation of taste and judgement amongst its consumer-readers. In 1827, the periodical's Fashionable Furniture section focused on a 'Gothic Whist-Table' (10 (Dec 1827): 56). After reflecting on the history of table design, the text goes on to approvingly discuss the design feature of the table, such as the well-positioned candlesticks which 'otherwise would have been of the persons engaged at play'. Finally, the piece reflects on the Gothic style of the piece, a style which the Repository of Arts seems to have particularly favoured. Given the 
magazine's association with the Pugin family, it is unsurprising that the periodical takes such an explicitly positive view of this style (Shimbo 2016: 202). Indeed, the text goes so far as to say that 'Great Britain exhibits more magnificence in this kind of furniture that any other country in Europe, particularly in this style being the only country at present where this beautiful style of architecture is understood' (10 (Dec 1827): 56). In other words, the Repository of Arts places Britain at the forefront of commerce and manufacture, as well as the arts more generally. Not only did the Repository of Arts see itself as a commercial vehicle for self-promotion, but it also explicitly credited itself with the 'cultivation of the arts' and the cultural education of its readership (11 (Apr 1814): 236).

\section{Patterns of British Manufacture: Fashion and the Patriotic Consumer}

The Repository of Arts' insistence on British pre-eminence was a consistent theme throughout the periodical. However, one area where this confident patriotism becomes more nuanced is in relation to dress. While early editions focused on 'Fashions for Ladies' which were implicitly British, later editions, from 1816 onwards, segregated 'London Fashions' from 'French Female Fashions' (2 (1816): 53). Intertwined with political relations, Anglo-French fashion conversations were always tense. Traditionally it had been 'France, whose Edicts govern Dress', as the English poet Soame Jenyns wrote in his 1742 work, Fashion, a Satire. To the English, these French fashions were simultaneously desirable and distasteful. As Aileen Ribeiro has argued, Anglo-French attitudes consisted of 'a complex mixture of envy, bafflement and dislike' (Ribeiro 1991). The cache of fashions from France was consistently strong throughout the century, and French a byword for style, elegance, and modishness. Yet France's fashionable superiority was diluted by the increasing desirability for decidedly English, rational styles of dress. Twinned with the recognition of the consumer as a patriotic economic force - an economic strategy France had acknowledged but failed to implement - English fashions enjoyed a resurgence of patriotic popularity from the 1790s to 1815 (Chrisman-Campbell 2015: 7). This view was repeated in the Repository of Arts, perpetuating a view of British economic and commercial superiority. It was in this climate of patriotic anglomania that the Repository of Arts was born (Bolton 2006).

Perhaps the most explicitly patriotic element of the publication - which was a key segment throughout the entire nineteen-year run - were the 'patterns of British manufacture'. Surrounded by an allegorical woodcut, these 'patterns' were samples of fabrics and ribbons, accompanied by descriptions of the items, and directions regarding where they might be acquired. In itself, this was a comparatively innovative inclusion, at least amongst British periodical publications. Through making the materiality of fabrics the core focus of these pages, Ackermann recognised how important being able to haptically and visually examine fabrics was to the female consumer (Smith 2012: 4). The importance of tactility to how readers engaged with the material practices of production and consumption, also highlighted in Chloe Wigston Smith's essay in this volume, are brought to the forefront. Just as the browsing process was depicted in the shop series, the patterns pages acted as a locum shop counter, over which the consumer-reader could view, touch, and become informed about the wide variety of goods available. 
It was broadly accepted that commerce 'was the engine which drove a state's power and wealth', and that manufacture and trade had become inextricably linked with national identity (Colley 1992: 64-72). The Repository of Arts proudly stated that the patterns included were always of British manufacture. Furthermore, the allegorical woodcuts that surrounded the patterns drove home this link between patriotism and the consumer, instilling a connection between the good of the country, and the material goods it produced, in the minds of the periodical's readership. The woodcuts that appeared came in two forms, which were used interchangeably. The first (see Plate 6) used the patriotic figure of Britannia at its forefront, where she sits with Neptune, father of Albion, and mythological god of the seas that surrounded and protected the nation, representing Britain's thalassocracy and naval dominance. From the mid-century, the Anti-Gallican Association had claimed Britannia as a key part of its anti-French iconography, and prominently included her in the society's coat of arms (Lindfield 2015). During the 1780s, such symbols - widely recognised and understood by an educated elite or middling consumer - became increasingly used on marketing ephemera; particularly that associated with international trade (Beddoes 2015). The symbols of British mercantile greatness proudly and unambiguously surrounds the fabric samples, drawing unmistakable associations between consumer goods, and patriotic support of the nation.

In the second allegorical woodcut (see Plate 7), these patriotic messages were extended through the use of iconography linked even more closely with trade and empire. Dominating the image, royal patronage was displayed in the regal crown and Prince of Wales plumes at the top and bottom of the image. These symbols are flanked by the masts of a trading ship: a clear reference to trade and empire. Reigning over the woodcut, at the centre of the image, is a bust of Britannia surrounded by classical accoutrements and references to the wider arts. To the left, a girl works industriously at her loom in an idealised image of manufacture, undoubtedly a reference to Penelope, wife of Odysseus, who was often represented as a weaver. To the right are displayed books and masks, referencing learning and the arts.

These 'patterns', or fabric samples, did not exist in isolation within their woodcuts. The Repository of Arts also included detailed information about what they could be used for, and where they could be obtained - much in the same vein as the information provided to the consumer-reader about the fashionable furniture. From the very first edition, the fabric samples were carefully integrated with the other features of the magazine. For example, the 'gold-coloured velvet', which provided one of the samples in the first volume, was linked to a fashion plate published only a few pages away (Plates 6 and 8). The text explicitly states that this fabric is ideal for the 'mantle of the morning gown' which appeared in the accompanying fashion plate, directly facilitating the reader to consume the fashions that the periodical advocated (1 (Jan 1809): 53).

Ackermann prefaced his introduction of this innovative marketing method to his periodical publication as follows:

Patterns afford the manufacturer an opportunity of circulating a new article more extensively in one day, than can be done by sending a dozen riders with it through the country. It will likewise afford persons at a distance from the metropolis the means of examining and estimating the merit of the fabric, and of being made acquainted with the tradesman from whom it may be purchased. (1 (Jan 1809): 58) 
Aside from the implicit self-promotion afforded in this statement, the centrality of the consumer to this plan is evident. The inclusion of fabric samples is not intended to act only as a means of education and information, but as a precursor to visiting the tradesmen from which it originated and making a purchase. In other words, the patterns of British manufacture not only promote metropolitan fashion information, they also advocate trade and commerce.

The fabrics included further supported the patriotic consumer message of the publication. For example, the 'cotton-thread shirting' to the bottom right of March 1813's patterns section was the subject of an 'imperial patent' (see Plate 7). As well as informing the reader that this fabric might be got from 'Mr Millard, the proprietor of the East India Warehouse, No. 16 Cheapside', the Repository of Arts goes on to declare that 'its superior durability, and its great economy' made it 'equal to, and nearly half the price of' foreign linens (9 (Mar 1813): 181). This particular fabric was not included as an example of a highly fashionable fabric for an elegant gown or pelisse, but rather as a patriotic consumption choice for practical garments.

The Repository of Arts even included samples of French émigrés' work, informing the reader that one particular fabric, a Persian kerseymere, was 'worked in tambour by a society of unfortunate, but industrious French emigrants, residing in the west of England' (6 (Dec 1811): 326). The italicised emphasis of the plight and origin of the manufacturers of this fabric encouraged readers to consume goods which were simultaneously fashionable, and which supported the national economy. The work of these French emigrants would still maintain the cachet of French fashionability, whilst supporting the national economy of their new home in England. A generation earlier, the Anti-Gallican Association had sought to 'discourage the introduction of French modes and oppose the importance of French commodities' partly in order to promote and preserve the prosperity of the British economy (Berg 1999: 77). However, now that desirable French fashions were available to a British market as a domestically produced product, they no longer necessarily threatened, but instead supported the national economy.

\section{Conclusion}

The Repository of Arts was part of a long narrative of print being used to disseminate ideas about fashionable consumption across the country with speed, dating back to at least the 1750s. The question of geographical scope and reach of fashionable objects and goods, articulated throughout the century in relation to the quasi-social networks of information and exchange provided in magazines, was a key issue in forming a recognisable, if not uniform, British consumer. Unlike her predecessors, such as the Gallery of Fashion (1794-1803) and La Belle Assemblée (1806-32), which are discussed in Chloe Wigston Smith's essay, this magazine was intended not only for personal improvement and entertainment, but also acted as a proponent of the country's national economic growth through trade and industry.

The London-centric approach to fashion consumption - dominated by an urban elite of retailers and merchants - further enabled the creation of an analogous national consumer. In essence, the Repository of Arts was a microcosmic representation of the values and preoccupations of the city, and its cultured and polite inhabitants, and in turn the nation as viewed and shaped by the state. In the publication's own 
words, it intended to be 'useful and polite', and to appeal to the affluent middling sort (1 (Jan 1809): 1). The consumption of fashionable goods - whether dress, furniture, or the periodical itself - was one element of this broader urban lifestyle, which also included discussion of politics, medical and naval reports, and information about fashionable furniture. This rounded, polite, urban populace was the epitome of the idealised British public, and was the crucible for the productive, patriotic consumer.

\section{Works Cited}

Ackermann, Rudolph, ed. 1809-28. The Repository of Arts. London: R. Ackermann.

Addison, Joseph. 1965. The Spectator. Ed. Donald F. Bond. 5 vols. Oxford: Clarendon Press.

Batchelor, Jennie and Cora Kaplan, eds. 2007. Women and Material Culture, 1660-1830. Basingstoke: Palgrave Macmillan.

Beard, Geoffrey W. and Judith Goodison. 1987. English Furniture 1500-1840. London: Phaidon Christie's.

Beddoes, Emalee. 2015. 'The National Drink: Advertising, the United Kingdom Tea Company and Nationalism'. Rule Britannia?: Britain and Britishness 1707-1901. Ed. Peter Lindfield and Christie Margrave. Newcastle: Cambridge Scholars Publishing. 101-20.

Berg, Maxine. 1994. The Age of Manufactures. London: Routledge.

-. 1999. 'New Commodities, Luxuries, and Their Consumers in Eighteenth-Century Britain'. Consumers and Luxury in Europe 1650-1850. Ed. Maxine Berg and Helen Clifford. Manchester: Manchester University Press. 63-87.

Berg, Maxine and Elizabeth Eger. 2002. 'The Rise and Fall of the Luxury Debates'. Luxury in the Eighteenth Century: Debates, Desires and Delectable Goods. Ed. Maxine Berg and Elizabeth Eger. London: Palgrave Macmillan. 7-27.

Berg, Maxine and Helen Clifford. 2007. 'Selling Consumption in the Eighteenth Century: Advertising and the Trade Card in Britain and France'. Cultural and Social History 4.2: $145-70$.

Bermingham, Ann. 2000. Learning to Draw: Studies in the Cultural History of a Polite and Useful Art. London: Paul Mellon.

Berry, Helen. 2002a. 'Polite Consumption: Shopping in Eighteenth-Century England'. Transaction of the Royal Historical Society 12: 375-94.

-. 2002b. 'Promoting Taste in the Provincial Press: National and Local Culture in EighteenthCentury Newcastle upon Tyne'. Journal for Eighteenth-Century Studies 25.1: 1-17.

Bianchi, Marina. 1998. 'Taste for Novelty and Novel Tastes: The Role of Human Agency in Consumption'. The Active Consumer: Novelty and Surprise in Consumer Choice. Ed. Marina Bianchi. London: Routledge. 64-87.

Boileau, Daniel. 1811. An Introduction to the Study of Political Economy. London: Cadell and Davies.

Bolton, Andrew. 2006. AngloMania: Tradition and Transgression in British Fashion. New York: Metropolitan Museum of Art.

Campbell, Richard. 1747. London Tradesman. London: T. Gardener.

Chrisman-Campbell, Kimberley. 2015. Fashion Victims: Dress at the Court of Louis XVI and Marie Antoinette. London: Yale University Press.

Colley, Linda. 1992. Britons: Forging the Nation, 1707-1837. London: Yale University Press.

Ford, John. 1983. Ackermann, 1783-1983. London: Ackermann.

Gascoigne, John. 1994. Joseph Banks and the English Enlightenment: Useful Knowledge and Polite Culture. Cambridge: Cambridge University Press.

Goggin, Maureen Daly and Beth Fowkes Tobin, eds. 2009. Women and the Material Culture of Needlework and Textiles, 1750-1950. Farnham: Routledge. 
Greig, Hannah. 2013. The Beau Monde: Fashionable Society in Georgian London. Oxford: Oxford University Press.

House of Commons Debate. 30 Apr 1838. 42, cc674-5.

Kowaleski-Wallace, Elizabeth. 1997. Consuming Subjects: Women, Shopping and Business in the Eighteenth Century. Chichester: Columbia University Press.

The Lady's Magazine; or, Entertaining Companion for the Fair Sex. 1770-1832 (1st ser. 1770-1819; 2nd ser. 1820-9; 3rd ser. 1830-2). London.

Lambert, Miles. 2009. 'Sent from Town: Commissioning Clothing in Britain During the Long Eighteenth Century'. Costume 43: 66-84.

Langford, Paul. 1989. A Polite and Commercial People: England 1727-1783. London: Guild Publishing.

Lindfield, Peter. 2015. 'National Identity Through Design: The Anglicisation of the Rococo in Mid-Eighteenth-Century Britain'. Rule Britannia?: Britain and Britishness 1707-1901. Ed. Peter Lindfield and Christie Margrave. Newcastle: Cambridge Scholars Publishing. 3-42.

Lister, Jenny. 2003. 'Twenty-Three Samples of Silk: Silks Worn by Queen Charlotte and the Princesses at Royal Birthday Balls, 1791-1794'. Costume 73: 51-65.

McCreery, Cindy. 2004. The Satirical Gaze: Prints of Women in Late Eighteenth-Century England. Oxford: Clarendon Press.

McDonald, Michelle Craig and Steven Topik. 2008. 'Americanizing Coffee: The Refashioning of a Consumer Culture'. Food and Globalisation: Consumption, Markets and Politics in the Modern World. Ed. Alexander Nuetsenadel and Frank Trentmann. Oxford: Berg. 109-27.

McKendrick, Neil, John Brewer, and John Harold Plumb. 1982. The Birth of a Consumer Society: The Commercialisation of Eighteenth-Century England. London: Europa.

Mackie, Erin. 2009. Rakes, Highwaymen, and Pirates: The Making of the Modern Gentleman in the Eighteenth Century. Baltimore: John Hopkins University Press.

Powell, Martyn J. 2013. 'Consumption: Commercial Demand and the Challenges to Regulatory Power in Eighteenth-Century Ireland'. Mercantilism Reimagined: Political Economy in Early Modern Britain and Its Empire. Ed. Philip J. Stern and Carl Wennerlind. Oxford: Oxford University Press. 282-302.

Ribeiro, Aileen. 1991. 'Fashion in the Eighteenth Century: Some Anglo-French Comparisons'. Textile History 22.2: 329-45.

Shimbo, Akiko. 2016. Furniture-Makers and Consumers in England, 1754-1851: Design as Interaction. London: Routledge.

Smith, Kate. 2012. 'Sensing Design and Workmanship: The Haptic Skills of Shoppers in Eighteenth-Century London'. Journal of Design History 25: 1-10.

-. 2014. Material Goods, Moving Hands: Perceiving Production in England, 1700-1830. Manchester: Manchester University Press.

Styles, John and Amanda Vickery, eds. 2006. Gender, Taste, and Material Culture in Britain and North America, 1700-1830. New Haven: Yale Center for British Art.

Trentmann, Frank. 2006. 'The Modern Genealogy of the Consumer: Meanings, Knowledge, and Identities Before the Age of Affluence'. Consuming Cultures, Global Perspectives: Historical Trajectories, Transnational Exchanges. Ed. John Brewer and Frank Trentmann. London: Berg. 19-70.

Vickery, Amanda. 1993. 'Women and the World of Goods: A Lancashire Consumer and Her Possessions, 1751-81'. Consumption and the World of Goods. Ed. John Brewer and Roy Porter. London: Routledge. 274-304.

-. 1998. The Gentleman's Daughter. London: Yale University Press.

-. 2006. 'His and Hers: Gender, Consumption and Household Accounting in EighteenthCentury England'. Ed. Lyndal Roper and Ruth Harris. The Art of Survival: Gender and History in Europe, 1450-2000 (Past and Present): 12-38.

-. 2009. Behind Closed Doors: At Home in Georgian England. London: Yale University Press. 